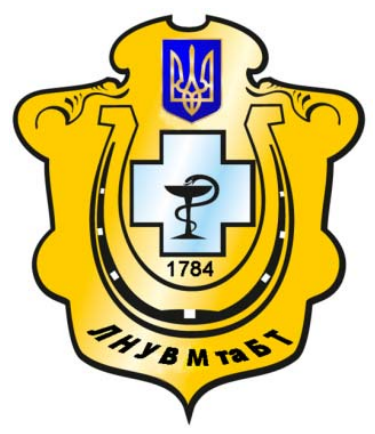

Науковий вісник Львівського національного університету ветеринарної медицини та біотехнологій імені С.3. Гжицького

Scientific Messenger of Lviv National University of Veterinary Medicine and Biotechnologies named after S.Z. Gzhytskyj

doi:10.15421/nvlvet6622

ISSN 2413-5550 print

ISSN 2518-1327 online

$\underline{\text { http://nvlvet.com.ua/ }}$

УДК 616.1

\title{
Біологічне значення системи антиоксидантного захисту організму тварин
}

Ю.Ю. Лавришин ${ }^{1}$, І.С. Вархоляк ${ }^{1}$, Т.В. Мартишук ${ }^{2}$, З.А. Гута ${ }^{1}$, Л.Б. Іванків ${ }^{1}$, О.Р. Паладійчук ${ }^{3}$, С.Д. Мурська ${ }^{4}$, Б.В. Гутий ${ }^{1}$, Д.Ф. Гуфрій ${ }^{1}$

bvh@ukr.net

${ }^{I}$ Львівський національний університет ветеринарної медицини та біотехнологій імені С.3. Гюсицького, вул. Пекарська, 50, м. Львів, 79010, Украӥна;

${ }^{2}$ Інститут біології тварин НААН, вул. В. Стуса, 38, м. Львів, 79034, Україна;

${ }^{3}$ Вінницький національний аграрний університет, вул. Сонячна, 3, м. Вінниця, 21008, Украӥна;

${ }^{4}$ Державний науково-дослідний контрольний інститут ветеринарних препаратів та кормових добавок, вул. Донецька, 11, м. Львів, 79019, Украӥна

В огляді літератури узагальнено дані про класифікаиію та характеристику системи антиоксидантного захисту організму тварин. Дана модель об'єднує в собі низку різних за своєю природою речовин. Кожен із компонентів антиоксидантної системи діє у тісному взаємозв'язку з іншими ї̈ структурними елементами, гармонійно доповнює, а в багатьох випадках підсилює дію один одного. Функиіональну основу системи антиоксидантного захисту формує глутатіонова система, складовими елементами якої є власне глутатіон і ензими, щуо каталізують реакції його зворотнього перетворення (окиснення↔відновлення).До даних ензимів відносять глутатіонпероксидазу, глутатіонредуктазу та глюкозо-6фосфатдегідрогеназу.

Більшість дослідників умовно розподіляють систему антиоксидантного захисту на ензимну та неензимну. До ензимної ланки системи антиоксидантного захисту належать: каталаза, супероксиддисмутаза, глутатіонпероксидаза, глутатіонредуктаза, глутатіонтрансфераза та інші ензими. До неензимної системи належать жиророзчинні вітаміни $A$, $E$ i $K$, водорозчинні вітаміни С і РР, біогенні аміни, глутатіон, каротиноїди, убіхінон, стерини. Як ензимна, так $і$ неензимна системи антиоксидантного захисту є наявні у кров'яному руслі. Активність ензимної антиоксидантної системи є дуже добре регульована $і$ залежить від віку тварин, фізіологічного стану, динаміки гормонів, інтенсивності синтезу антиоксидантного ензиму, рН середовища, наявності коферментів, інгібіторів, активаторів та інших чинників. Неензимна ланка антиоксидантної системи не потребує стількох багатьох регуляторів так, як сама хімічна речовина - антиоксидант вступає у хімічну реакиію з радикалом. Змінюватись може хіба що швидкість реакиії.

Ключові слова: фармакологія, система антиоксидантного захисту, антиоксиданти, ензимна та неензимна ланки

\section{Биологическое значение системы антиоксидантной защиты организма животных}

\author{
Ю.Ю. Лавришин ${ }^{1}$, И.С. Вархоляк ${ }^{1}$, Т.В. Мартышук², 3.А. Гута ${ }^{1}$, Л.Б. Иванкив ${ }^{1}$, \\ Е.Р. Паладийчук ${ }^{3}$ С.Д. Мурська ${ }^{4}$, Б.В. Гутий ${ }^{1}$, Д.Ф. Гуфрий ${ }^{1}$ \\ bvh@ukr.net

\footnotetext{
${ }^{1}$ Львовский нацииональный университет ветеринарной медицины и биотехнологий имени С.3. Гжицукого, ул. Пекарская, 50, г. Львов, 79010, Украина

${ }^{2}$ Институт биологии животных НААН, ул. В. Стуса, 38, г. Львов, 79034, Украина

${ }^{3}$ Винницукий нацчиональный аграрный университет, ул. Солнечная, 3, г. Винница, 21008, Украина
}

\footnotetext{
Citation:

Lavryshyn, Y.Y., Varkholyak, I.S., Martyschuk, T.V., Guta, Z.A., Ivankiv, L.B., Paladischuk, O.R., Murska, S.D., Gutyj, B.V., Gufriy, D.F. (2016). The biological significance of the antioxidant defense system of animals body. Scientific Messenger LNUVMBT named after S.Z. Gzhytskyj, 18, 2(66), $100-111$.
} 
${ }^{4}$ Государственный научно-исследовательский контрольный институт ветеринарных препаратов и кормовых добавок, ул. Донеикая, 11, г. Львов, 79019, Украина

В обзоре литературы обобщены данные о классификации и характеристике системы антиоксидантной защиты организма животных. Данная модель объединяет в себе ряд различных по своей природе веществ. Каждый из компонентов антиоксидантной системы действует в тесной взаимосвязи с другими ее структурными элементами, гармонично дополняет, а во многих случаях - усиливает действие друг друга. Функииональную основу системы антиоксидантной защить формирует глутатионовоя система, составными элементами которой являются собственно глутатион, энзимы, которые катализируют реакции его обратного преобразования (окисления ↔ восстановления). К данным ферментам относят глутатионпероксидазы, глутатионредуктазы и глюкозо-6-фосфатдегидрогеназы.

Большинство исследователей условно распределяют систему антиоксидантной защить на ферментную и неферментную. До ферментного звена системы антиоксидантной защчиты относятся: каталаза, супероксиддисмутаза, глутатионпероксидаза, глутатионредуктаза, глутатионтрансферазы и другие энзимы. К неферментной системы относятся жирорастворимые витамины $A$, Е и К, водорастворимые витамины $C$ и РP, биогенные амины, глутатион, каротиноиды, убихинон, стерины. Активность ферментной антиоксидантной системы очень хорошо регулируемая и зависит от возраста животных, физиологического состояния, динамики гормонов, интенсивности синтеза антиоксидантных ферментов, рН среды, наличия коферментов, ингибиторов, активаторов и других факторов. Неферментное звено антиоксидантной системы не требует стольких многих регуляторов так, как химическое вещество - антиоксидант - вступает в химическую реакииию с радикалом. Меняться может разве что скорость реакиии.

Ключевые слова: фармакология, система антиоксидантной защиты, антиоксиданты, ферментное и неферментное звена

\title{
The biological significance of the antioxidant defense system of animals body
}

\author{
Y.Y. Lavryshyn ${ }^{1}$, I.S. Varkholyak ${ }^{1}$, T.V. Martyschuk ${ }^{2}$, Z.A. Guta ${ }^{1}$, L.B. Ivankiv ${ }^{1}$, \\ O.R. Paladischuk ${ }^{3}$, S.D. Murska ${ }^{4}$, B.V. Gutyj ${ }^{1}$, D.F. Gufriy ${ }^{1}$ \\ bvh@ukr.net \\ ${ }^{1}$ Lviv National University of Veterinary Medicine and Biotechnologies named after S.Z. Gzhytskyi, \\ Pekarska Str., 50, Lviv, 79010, Ukraine \\ ${ }^{2}$ Institute of Animal Biology NAAS, V. Stus Str., 38, Lviv, 79034, Ukraine \\ ${ }^{3}$ Vinnytsya National Agrarian University, Soniachna Str.,3, Vinnytsya, 21008, Ukraine \\ ${ }^{4}$ State scientific research control institute of veterinary medicinal products and feed additives, \\ Donets'ka Str., 11, Lviv, 79019, Ukraine
}

\begin{abstract}
In the review of the literature it was generalized the data due to the classification and characterization of antioxidant protection system of animals body. This model combines a number of different by its nature substances. Each of the components of the antioxidant system operates in close relationship with its other structural elements, harmoniously, and in many cases complements and in many cases - enhances the action of each other. Glutathione system forms functional basis of antioxidant defense system, constituent elements of which has its own glutathione and enzymes, which catalyze the reaction of its reverse transformation (oxidation $\leftrightarrow$ recovery). Glutathione peroxidase, glutathione reductase and glucose-6-phosphate dehydrogenase are attributed to these

Most researchers conventionally distributed antioxidant defense system in enzyme and non-enzyme. Catalase, superoxide dismutase, glutathione peroxidase, glutathione reductase, glutathione transferase and other enzymes are included to enzymatic link of antioxidant defense system. Fat-soluble vitamins $A, E$ and $K$, water-soluble vitamins $C$ and PP, biogenic amines, glutathione, carotenoids, ubiquinone, sterols are included to non-enzyme system. As the enzyme, as non-enzyme antioxidant defense system is present in the bloodstream. The activity of enzymatic antioxidant system is well regulated and depends on the age of the animals, physiological condition, the dynamics of hormone, synthesis intensity of antioxidant enzyme, pH medium, the presence of coenzymes, inhibitors, activators, and other factors. Non-enzyme link of antioxidant system does not need so many regulators as the most chemical substance - antioxidant - enters into chemical reaction with the radical. The rate of reaction may be only changed.
\end{abstract} enzymes.

Key words: pharmacology, antioxidant protection system, antioxidants, enzyme and non-enzyme link.

\section{Вступ}

Антиоксидантна система захисту організму тварин контролює і гальмує всі етапи реакцій утворення вільних радикалів, починаючи від їх ініціації і закінчуючи утворенням гідроперекисів та малонового діальдегіду (Danchuk, 2001; Bjelenichev et al., 2002; Akymyshyn et al., 2014).

Основний механізм контролю даних реакцій пов'язаний із ланцюгом оборотних окисно-відновних реакцій іонів металів, аскорбату, токоферолу, глутатіону та інших речовин. До того ж значення цих методів, особливо, важливо для збереження довго існуючих макромолекул нуклеїнових кислот і білків, деяких складових мембран (Bjelenichev et al., 2002).

Дана система об'єднує в собі низку різних за сво$є ю$ природою речовин. Кожен із компонентів антиоксидантної системи діє у тісному взаємозв'язку 3 іншими ії структурними елементами, гармонійно доповнює, а в багатьох випадках - підсилює дію один одного. Функціональну основу системи антиоксидантного захисту формує глутатіонова система, складовими елементами якої $є$ власне глутатіон і ензими, що каталізують реакції його зворотного перетворення 
(окиснення ↔ відновлення). До даних ензимів відносять глутатіонпероксидазу, глутатіонредуктазу та глюкозо-6-фосфатдегідрогеназу. Окрім вказаних антиоксидантів відносять також каталазу, пероксидазу та супероксиддисмутазу, які, здатні каталізувати реакції прямого руйнування пероксидних сполук в організмі людини і тварин (Dvinskaja and Shubin, 1986; Antonjak et al., 2000; Bjelenichev et al., 2002).

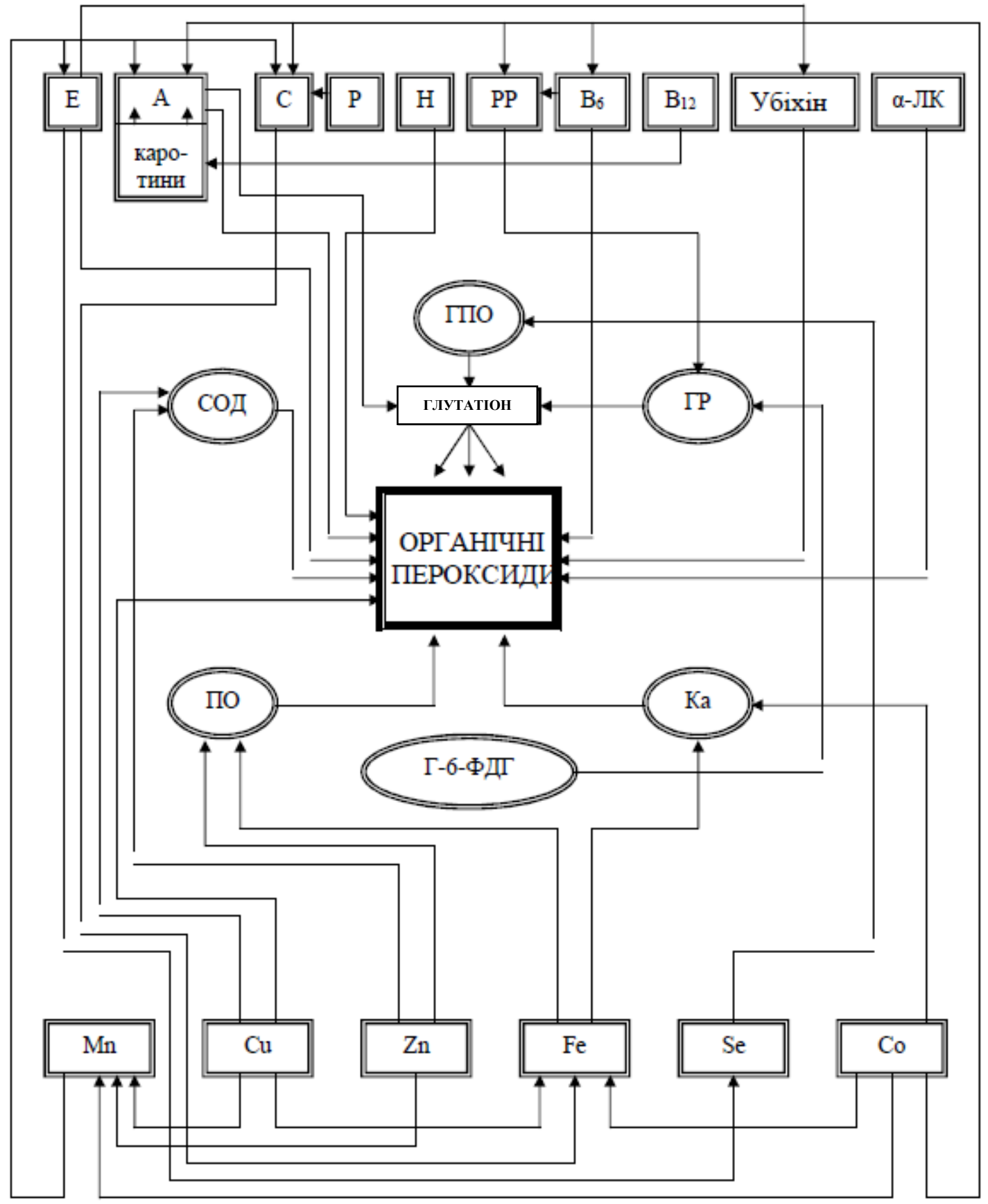

Рис. 1. Схема взаємозв'язків між структурно-функціональними компонентами системи антиоксидантного захисту організму тварин (Zavijs'kyj, 2005).

Глутатіон (L- $\gamma$-глутаміл-L-цистеїніл-гліцин) біологічно активний трипептид, який виявляють у всіх організмах. Він складається із залишків $\gamma-$ глутамінової кислоти, цистеїну та гліцину.

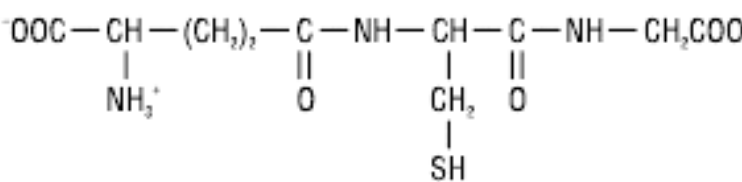

Після взаємодії з кислотами, глютамінова кислота, що входить до складу глутатіону, утворює пептидний зв'язок із цистеїном за рахунок $\gamma$-карбоксильної групи (Kulinskij and Kolesnichenko, 1990).

Глутатіон виконує в організмі тварин багатогранні і дуже важливі функції: бере участь у знешкодженні ксенобіотиків; захищає від активних кисневих сполук; підвищує резистентність клітин до негативного впливу стресфакторів; відновлює і ізомеризує дисульфідні зв'язки; виконує коензимні функції; впливає на біоси- 
нтез нуклеїнових кислот; спричиняє вплив на проліферацію клітин та підтримує функціональний стан біологічних мембран. Глутатіон відновлений є основним сірковмісним антиоксидантом в організмі тварин (Vishhur, 2006). Він захищає сульфгідрильні групи глобіну, мембрани еритроцитів, двовалентне залізо від дії окиснювачів.

Встановлено, що низька концентрація глутатіону в клітинах, зокрема, в еритроцитах, призводить до активації перекисного окиснення ліпідів, що встановлено за деяких форм гемолітичних анемій (Bjelenichev et al., 2002; Vasyliv and Gnatush, 2011; Akymyshyn et al., 2014).

Глутатіон є центральним компонентом антиоксидантних систем майже всіх клітин і органів (Ponkalo, 2012). Його антиоксидантна дія пов'язана 3 перенесенням сульфгідрильних груп. За активності глутатіонпероксидази він перетворюється на дисульфід. Глутатіонредуктаза переводить глутатіон у відновлену форму (Kava et al., 2012). Глутатіон-S-трансфераза здійснює дезінтоксикацію токсичних сполук у гепатоцитах шляхом перенесення на них атомів сірки.

Глутатіонпероксидаза - $є$ одним 3 ключових ензимів антиоксидантної системи організму тварин, основною функцією якого є руйнування і інактивація перекису водню і гідроперекисів (пероксидних радикалів) - токсичних сполук кисню. ГП є тетрамером, що складається 3 чотирьох ідентичних сферичних субодиниць. Кожна субодиниця містить по одному атому селену, на тетрамер $є$ два активних GSHзв'язувальних центрів. За зменшення активності ГП знижується стійкість організму до окиснювального ураження, що може призводити до розвитку вільнорадикальної патології. Даний ензим є двох типів: селен залежний (ГП-I) і селен незалежний (ГП-II) (Dubinina et al., 1983; Vorobec', 2004). Понад 70\% ГП локалізується у цитозолі та 25-30\% - у матриксі мітохондрій (Baglaj et al., 2011). Даний ензим виявлено у всіх тканинах еукаріот і більшості прокаріот, у яких відбуваються окисні процеси.

Глутатіонпероксидаза забезпечує захист мембран клітин від руйнівної дії пероксидних радикалів. До того ж вона каталізує розпад перекису водню і окиснює глутатіон (Kulinskij and Kolesnichenko, 1993; Mohazzab et al.,1999).

ГП каталізує реакцію відновлення глутатіоном нестійких органічних гідропероксидів, включає гідропероксиди поліненасичених жирних кислот, стабільні сполуки - оксикислоти:

$$
2 \mathrm{GSH}+\mathrm{ROOH} \rightarrow \mathrm{GSSG}+\mathrm{ROH}+\mathrm{H}_{2} \mathrm{O}
$$

Усі ГП , подібно каталази , здатні також утилізувати перекис водню :

$$
2 \mathrm{GSH}+\mathrm{H}_{2} \mathrm{O}_{2} \rightarrow \mathrm{GSSG}+2 \mathrm{H}_{2} \mathrm{O}
$$

Також ГП-I бере участь у нейтралізації пероксинітриту:

$$
2 \mathrm{GSH}+\mathrm{ONOO}-\rightarrow \mathrm{GSSG}+\mathrm{NO}+\mathrm{H}_{2} \mathrm{O}
$$

Спорідненість ГП до $\mathrm{H}_{2} \mathrm{O}_{2}$ вища, ніж у каталази, тому перша ефективніше працює за низьких концентраціях перекису водню, в той же час у захисті клітин окисного стресу, викликаного високими концентраціями $\mathrm{H}_{2} \mathrm{O}_{2}$, ключова роль належить каталазі. В цілому ж , ГП значно важливіша, ніж каталаза, так як каталаза знаходиться в мікросомах , а ГП - в цитозолі і мітохондріях, спорідненість ГП до пероксиду водню значно вища, тому $\mathrm{H}_{2} \mathrm{O}_{2}$ виводиться ГП. Ензим відіграє головну роль у валовому метаболізмі $\mathrm{H}_{2} \mathrm{O}_{2}$. Спільно 3 токоферолом ГП гідроперекисів фосфоліпідів практично повністю пригнічує ПОЛ у біомембранах (Vishhur, 2006).

Глутатіонредуктазна / Глутатіонпероксидазна (ГР / ГП) система $\epsilon$ найважливішим компонентом антиоксидантного захисту організму, яка підтримуює на стаціонарному рівні інтенсивність перебігу вільнорадикального окиснення (Vlasova et al., 1990). Завдяки функціонуванню ГР / ГП системи у клітинах ссавців забезпечується дезінтоксикація гідроперекисів та перекисів, які $є$ основним джерелом гідроксильного радикала, що утворюється в реакції Фентона за наявності іонів $\mathrm{Fe}^{2+}$.

Глутатіонредуктаза - ензим класу оксидоредуктаз, що каталізує відновлення окисненого глутатіону. ГР широко поширений флавіновий ензим, який підтримує високу внутрішньоклітинну концентрацію GSH, каталізує оборотне NADP·H - залежне відновлення GSSG 3 утворенням двох молекул GSH (Guberuk et al., 2012).

$$
\mathrm{GSSG}+\mathrm{NADP} \cdot \mathrm{H}+\mathrm{H}+\rightarrow 2 \mathrm{GSH}+\mathrm{NADP}
$$

ГР міститься, в основному, в розчинній частині клітини.

Глутатіонредуктаза має високу специфічність до глутатіону, проте 3 низькою швидкістю може каталізувати відновлення низки інших сполук, що містять дисульфідні зв'язки, і крім основної, глутатіонвідновлювальної активності здатна проявляти трансгідрогеназну, електронтрансферазну і діафоразну активності, хоча і в значно меншому ступені (Bjelenichev et al., 2002).

Глутатіонредуктаза являє собою димер із молекулярною масою 105 кДа, що складається з двох ідентичних субодиниць, кожна з яких містить чотири структурних домени. Субодиниці пов'язані між собою дисульфідним зв'язком, що є центром симетрії молекули глутатіонредуктази. Кожний поліпептидний ланцюг містить одну молекулу FAD, 30\% - альфа-спіральних ділянок і 30\% бета-складчастих структур (Vlasova et al., 1990).

На одній стороні кожної субодиниці у складі FAD - домена знаходиться FAD - зв'язувальна ділянка, а на протилежній в складі NADPH - домена - ділянка зв'язування NADPH. За цих умов ділянки зв'язування динуклеотидів забезпечують максимальне зближення функціонально активних флавінових і нікотинамідних частин молекул коензимів у глибокій кишені, тоді як аденілові залишки розташовуються ззовні і віддалені один від одного на відстань 2,9 нм (Bjelenichev et al., 2002). Г.Шульц припускає, що динуклеотидзвязува- 
льні домени молекули глутатіонредуктази утворюються в результаті дуплікації гена , тобто еволюційно споріднені (Vlasova et al., 1990; Bjelenichev et al., 2002).

Глутатіонтрансферази відносять до ензимів, які нейтралізують токсичний вплив різних гідрофобних i електрофільних сполук шляхом їх кон'югації з відновленим глутатіоном. Даний ензим локалізований переважно в цитозолі клітин. Основна функція глутатіонтрансферази - захист клітин від ксенобіотиків та продуктів ПОЛ за допомогою їх відновлення, приєднання до субстрату молекули глутатіону або нуклеофільного заміщення гідрофобних груп (Bjelenichev et al., 2002):

$$
\begin{gathered}
\mathrm{ROOH}+2 \mathrm{GSH} \rightarrow \mathrm{ROH}+\mathrm{GSSG}+\mathrm{H} 2 \mathrm{O} \\
\mathrm{R}+\mathrm{GSH} \rightarrow \mathrm{HRSG} \\
\mathrm{RX}+\mathrm{GSH} \rightarrow \mathrm{RSG}+\mathrm{HX}[]
\end{gathered}
$$

ГТ здатні відновлювати гідропероксидні-групи окиснених фосфоліпідів безпосередньо в мембранах без їх попереднього фосфоліпідного гідролізу вільними жирними кислотами. Цей ензим кон'югує з глутатіоном токсичні продукти ПОЛ і таким чином сприяють їх виведенню з організму (Bjelenichev et al., 2002). Саме таким чином, ГТ є важливим компонентом антиоксидантного захисту, особливо від ендогенних метаболітів, що утворюють після окиснювального стресу.

Глутатіонтрансферази відіграють важливу роль в ендогенному метаболізмі: вони пов'язують і транспортують жовчеві кислоти, білірубін, захищають організм від окиснювального стресу шляхом відновлення гідропероксидів жирних кислот і нуклеотидів. Глутатіонтрансферази беруть участь в утворенні та метаболізмі гормонів (простагландинів, лейкотрієнів, естрогенів) (Vishhur, 2006).

Розрізняють глутатіонтрансферази, які взаємодіють 3 катіонами (у печінці, нирках та кишечнику) i аніонами (головний мозок, легені. селезінка, еритроцити, плацента). Залежно від специфічності субстрату також розрізняють глутатіонтрансферазу, яка взаємодіє 3 алкенами, епоксидами, алкіленами, арилами, алканами, ентеротоксинами. Максимальна концентрація глутатіонтрансферази виявлена в печінці (Bjelenichev et al., 2002). В основному глутатіонтрансферази локалізовані в цитозолі і ендоплазматичному ретикулумі, але також виявляються в ядрах і мітохондріях.

Глюкозо-6-фосфатдегидрогеназа - пусковий ензим пентозофосфатного циклу окиснення вуглеводів. Для відновлення окисненого глутатіону ГР в якості донара водню використовується NADPH, який утворюється в пентозофосфатному циклі (Bjelenichev et al., 2002). Ензим, що каталізує початкову реакцію пентозофосфатного циклу: відновлення глюкозо-6фосфату в 6-фосфоглюконат. Вона складається 3 двох типів субодиниць, які утворюються з 479 амінокислотних залишків та мають один і той же $\mathrm{COOH}-$ кінцева ділянка, але різні $\mathrm{NH}_{2}$ - кінці. Ці субодиниці розрізняються за довжиною і послідовністю амінокислот. Реакцію, яку каталізує Г-6-ФДГ, з кінетичної точки зору можна розглядати як двосубстратну реакцію, що протікає за участю субстрату і коензиму, який виконує роль другого субстрату. Ензим дуже сильно інгібується NADPH і ATP, за типом конкурентного інгібування (Bjelenichev et al., 2002).

Глюкозо-6-фосфатдегідрогеназа - ензим цитоплазми, який входить до шляху перетворення глюкози, що забезпечує утворення клітинного NADPH з NADP +. NADPH необхідний для підтримки рівня відновленого глутатіону в клітині, синтезу жирних кислот i ізопреноїдів.

Г-6-ФДГ - ензим обміну вуглеводів, велика кількість ензиму міститься в еритроцитах. За відсутності Г-6-ФДГ в еритроцитах відбувається порушення функціонування гемоглобіну. Вроджений дефіцит Г6-ФДГ еритроцитів відноситься до поширених спадкових аномалій (ензимопатій) і проявляється клінічно у вигляді гемолітичної анемії (Bjelenichev et al., 2002).

Супероксиддисмутази - металовмісні ензими, які каталізують реакцію інактивації тобто дисмутації супероксидних радикалів. Як правило, ензими, що володіють СОД-активністю знаходяться всередині клітини (Dubinina et al., 1983).

Механізм дії супероксиддисмутази можна представити за схемою (Е-Cu2 +-ензим):

$$
\begin{gathered}
\mathrm{E}-\mathrm{Cu}^{2+}+\mathrm{O}_{2}^{-} \rightarrow \mathrm{E}-\mathrm{Cu}^{+}+\mathrm{O}_{2} \\
\mathrm{E}-\mathrm{Cu}^{+}+\mathrm{O}_{2}^{-}+2 \mathrm{H}^{+} \rightarrow \mathrm{E}-\mathrm{Cu}^{2+}+\mathrm{H}_{2} \mathrm{O}_{2}
\end{gathered}
$$

Він $є$ основним із ензимів внутрішньоклітинного антирадикального захисту аеробних організмів, каталізує реакцію дисмутації супероксидних радикалів 3 утворенням перекису водню і кисню, і таким чином бере участь у регуляції вільно радикальних процесів у живих клітинах на початковій стадії. СОД має кілька ізоензимних форм. СОД є внутрішньоклітинним ензимом і в міжклітинних рідинах (лімфа, плазма, синовіальна рідина) швидко руйнується (Duh and Vovk, 2010).

Супероксиддисмутаза в крові умовно ділиться на ізоензими і часто називається металоензимом, розрізняють три форми: $\mathrm{Fe}-, \mathrm{Zn}-\mathrm{Cu}-$ та $\mathrm{Mn}-$ залежні $\mathrm{COД.}$ Метали виконують каталітичну функцію, які послідовно відновлюються і окиснюються в активному центрі ензиму (Cehmistrenko, 1999).

Незважаючи на високу специфічність, у певних умовах СОД може взаємодіяти з перекисом водню і виступати як прооксидант, ініціюючи утворення супероксидного аніону і гідроксильного радикалу. Важливо відзначити, що як зниження, так і підвищення активності СОД є причиною розвитку патологічних процесів. У першому випадку внаслідок недостатнього захисту від активних форм кисню, у другому - в результаті посилення цитотоксичної дії перекису водню, що утворюється в результаті дисмутації супероксиду (Bjelenichev et al., 2002).

Супероксиддисмутаза в крові як первинний антиоксидант підтримує та контролює рівень вільних радикалів і таким чином створює умови нормального використання кисневого середовища організму. Крім того СОД успішно деактивує один 3 найнебезпечні- 
ших для клітин токсинів - АФК, тобто активні форми кисню. Після розпаду АФК утворюються перекис водню, який здатний пошкодити супероксиддисмутазу (ії молекули), з цієї причини СОД завжди функціонує разом із каталазою. Каталаза досить швидко розщеплює шкідливу для СОД перекис на воду і кисень (Cehmistrenko, 1999).

Супероксиддисмутаза 3 каталазою та іншими антиоксидантними ензимами захищає організм від високотоксичних кисневих радикалів.

Каталаза - ензим класу оксиредуктаз, що бере участь у дезінтоксикації нерадикальної активної форми кисню $-\mathrm{H}_{2} \mathrm{O}_{2}$. Хромопротеїд, складається 3 чотирьох ідентичних субодиниць 3 молекулярною масою 62 000. Каталізує розкладання $\mathrm{H}_{2} \mathrm{O}_{2}$ до води і кисню (Bjelenichev et al., 2002; Nazaruk et al., 2015).

Молекула каталази складається 3 4-х субодиниць, кожна містить гем, який входить до складу активного центру і пов'язаний з молекулою NADPH. До активного центру йде вузький канал, який запобігає проникненню значно великих молекул, ніж $\mathrm{H}_{2} \mathrm{O}_{2}$. За дисоціації субодиниць каталаза втрачає свою активність. До активного центру каталази входить тривалентне залі3о, протопорфірин, який взаємодіє 3 перекисом водню за каталазним, або за пероксидазним механізмом,

залежно від концентрації субстрату (Bjelenichev et al., 2002; Nazaruk et al., 2016).

Ензим, локалізований переважно в пероксисомах клітин. Велика молекулярна маса ензиму перешкоджає його проникненню через клітинну мембрану (Bjelenichev et al., 2002). Розкладання $\mathrm{H}_{2} \mathrm{O}_{2}$ каталазою здійснюється у два етапи.

$$
\begin{gathered}
\mathrm{CAT}+\mathrm{H}_{2} \mathrm{O}_{2} \rightarrow \mathrm{CAT}-\mathrm{H}_{2} \mathrm{O}_{2} \\
\mathrm{CAT}-\mathrm{H}_{2} \mathrm{O}_{2}+\mathrm{H}_{2} \mathrm{O}_{2} \rightarrow \mathrm{CAT}+2 \mathrm{H}_{2} \mathrm{O}+\mathrm{O}_{2}
\end{gathered}
$$

За цих умов в окисненому стані каталаза працює i як пероксидаза, яка каталізує окиснення спиртів або альдегідів:

$$
\mathrm{CAT}-\mathrm{H}_{2} \mathrm{O}_{2}+>\mathrm{CHOH} \rightarrow \mathrm{CAT}+2 \mathrm{H}_{2} \mathrm{O}+>\mathrm{C}=\mathrm{O}
$$

Каталітична швидкість каталази досить висока i складає приблизно 45 тис. молекул $\mathrm{H}_{2} \mathrm{O}_{2}$ за секунду. Найбільша концентрація каталази у печінці. У пероксисомах гепатоцитів частина каталази становить $40 \%$ всіх білків, також висока іiі концентрація в мітохондріях і ендоплазматичному ретикулумі.

\begin{tabular}{|c|c|c|c|}
\hline № п/п & Компоненти САЗ & Біоорганічна сполука & Біохімічні ефекти \\
\hline 1. & Глутатіон & $\begin{array}{l}\text { Трипептид: у-глутамініл- } \\
\text { цистеїніл-гліцин }\end{array}$ & $\begin{array}{l}\text { Знешкодження ОП: перенесення водню в пероксидазних i } \\
\text { редуктазних реакціях. }\end{array}$ \\
\hline 2. & Ензими & $\begin{array}{l}\text { Глутатіонпероксидаза } \\
\text { Глутатіонредуктаза } \\
\text { Глюкозо-6-фосфат- дегідро- } \\
\text { геназа } \\
\text { Каталаза } \\
\text { Пероксидази } \\
\text { Супероксиддисмутаза }\end{array}$ & $\begin{array}{l}\text { Каталізує реакції взаємодії глутатіонуз гідропероксидом. } \\
\text { Каталізує реакції зворотнього відновлення глутатіону. } \\
\text { Генератор NADPH для функціонування глутатіонредук- } \\
\text { тази. } \\
\text { Каталізує розщеплення пероксиду водню. } \\
\text { Каталізують руйнування пероксиду водню. } \\
\text { Каталізує реакції знешкодження пероксидних сполук. }\end{array}$ \\
\hline 3. & Вітаміни & $\begin{array}{l}\text { а-токоферол (вітамін Е) } \\
\text { Ретинол (вітамін А) } \\
\text { L-аскорбінова кислота (віта- } \\
\text { мін C) } \\
\text { Рутин (вітамін P) } \\
\text { Нікотинамід (вітамін PP, віта- } \\
\text { мін В } \text { ( }_{\text {) }} \\
\text { Біотин (вітамін Н) } \\
\text { Піридоксин } \\
\text { Ціанокобаламін (вітамін } \mathrm{B}_{12} \text { ) }\end{array}$ & $\begin{array}{l}\text { Інгібітор вільних радикалів; стабілізація біологічних } \\
\text { мембран (протидія їх перекисному окисненню); захист } \\
\text { селену від окиснення; участь в синтезі убіхінону. } \\
\text { Акцептор перекисних радикалів; участь в синтезі L- } \\
\text { цистеїну (активного компонента глутатіону). } \\
\text { Активатор каталази; участь в окисно-відновних реакці- } \\
\text { ях в організмі; регенерація відновленої форми Fe. } \\
\text { Захист вітаміну С від окиснення. } \\
\text { У складі NADP та NADPH забезпечує каталітичну дія- } \\
\text { льність глутатіонредуктази. } \\
\text { Перехоплення гідроксильних радикалів. } \\
\text { Перехоплення (акцептор) гідроксильних груп. } \\
\text { Синтез ретинолу з провітамінів (а-, } \beta-\text { і у-каротинів). }\end{array}$ \\
\hline 4. & $\begin{array}{c}\text { Вітаміно-подібні } \\
\text { речовини }\end{array}$ & $\begin{array}{l}\text { Убіхінон } \\
\text { а-ліпоєва кислота }\end{array}$ & $\begin{array}{l}\text { Перенесення атомів водню від дегідрогеназ системи } \beta- \\
\text { окиснення жирних кислот. } \\
\text { Знешкодження органічних пероксидів. }\end{array}$ \\
\hline 5. & $\begin{array}{l}\text { Метали-мікро- } \\
\text { елементи }\end{array}$ & $\begin{array}{l}\text { Селен }(\mathrm{Se}) \\
\text { Ферум (Fe) } \\
\text { Купрум (Cu) } \\
\text { Цинк (2п) } \\
\text { Кобальт (Co) } \\
\text { Марган (Mn) }\end{array}$ & $\begin{array}{l}\text { Активатор ГПО. } \\
\text { Активатор каталази, пероксидаз. } \\
\text { Активатор мідьоксидази і СОД; стимуляція засвоєння Fe i } \\
\text { Мп. } \\
\text { Активатор пероксидази і СОД; стимуляція засвоєння Мп. } \\
\text { Активатор каталази; участь в депонуванні в тканинах } \\
\text { вітамінів А, С, РP і синтезі вітаміну В } 6 \text {; стимуляція засво- } \\
\text { єння Fе, Мn. } \\
\text { Стимуляція біологічних ефектів вітамінів А, Е, С. }\end{array}$ \\
\hline
\end{tabular}

Табличяя 1

Система антиоксидантного захисту організму (Zavijs'kyj, 2005) 
Ефективне функціонування АОС забезпечують також вітаміни (А, Е, C, P, PP, H, B 6 , B 12 ), вітаміноподібні речовини (убіхінон, ліпоєва кислота), а також окремі мікроелементи-метали (селен, купрум, кобальт, ферум, цинк і марган) (Bjelenichev et al., 2002; Nazaruk et al., 2016). Механізми антиоксидантної дії окремо взятих вітамінів, вітаміноподібних речовин та мікроелементів зумовлені особливостями їх хімічної структури, а також специфікою участі в процесах метаболізму. Про роль вітамінів і вітаміноподібних речовин у забезпеченні нормальної роботі АОС вказують наступні факти.

Вітамін $A$ є потужним акцептором перекисних радикалів, що пов'язано із його здатністю активно перехоплювати пероксидні сполуки (Bjelenichev et al., 2002; Leshovs'ka et al., 2007; Nazaruk et al., 2016). Антиоксидантні ефекти даного вітаміну мають також і опосередкований характер, оскільки ретинол, як відомо, бере активну участь у синтезі сірковмісних амінокислот в організмі, зокрема L-цистеїну. Останній $\epsilon$, водночас, структурним компонентом глутатіону i, завдяки наявності у іiі складі функціонально високоактивної сульфгідрильної групи - визначальною в реалізації його антиоксидантних ефектів. Характеризуючи антиоксидантні властивості ретинолу, слід згадати про його природні харчові попередники тобто провітаміни $\mathrm{A}-\alpha-, \beta-\mathrm{i} \gamma-$-каротини, 3 яких в у клітинах печінки синтезується вітамін А. Стимулятором біологічних у тому числі і антиоксидантних ефектів ретинолу є йони маргану, а йони кобальту сприяють депонуванню вітаміну А у тканинах (Bjelenichev et al., 2002).

Вітамін А бере активну участь в окисно-відновних процесах, регуляції синтезу білків, сприяє нормальному обміну речовин, функції клітинних і субклітинних мембран. Крім того, відіграє важливу роль у формуванні кісток і зубів, а також жирових відкладень. До того ж необхідний для росту нових клітин, сповільнює процес старіння (Guberuk et al., 2015).

Синтез вітаміну А відбувається в ентероцитах і peгулюється ензимом $\beta$-каротин-15,15-диоксигеназою, на активність останньої, а відповідно і швидкість трансформації каротиноїдів у вітамін А, впливає інший ензим слизової оболонки кишечника - NADP (Bjelenichev et al., 2002).

Вітамін А бере участь у процесах обміну речовин організму: синтез білка родопсину, нуклеїнових кислот і білків, зокрема, білків сироватки крові (Popyk, 2012). За виникнення А-вітамінозу гальмується синтез альбумінів у печінці, послаблюється включення амінокислот у білки. Ретинол необхідний для нормального обміну ліпідів. У мітохондріях печінки, за дефіциту цього вітаміну, знижується вміст ліпідів і фосфоліпідів, ненасичених жирних кислот за одночасного збільшення холестеролу i тригліцеролів (Bjelenichev et al., 2002; Leshovs'ka et al., 2005; Gromova and Rebrov, 2007).

Вітамін E (токоферол) охороняє вітамін А від окиснення як в кишечнику, так і в тканинах. Якщо $є$ нестача вітаміну Е, то вітамін А не буде засвоюватись у відповідній кількість, і тому ці два вітаміни потріб- но приймати разом (Danchenko, 2002; Bilash et al., 2011).

Механізм фармакологічної дії вітаміну Е полягає у тому, що він запобігає окисненню жирів, жирних кислот та стеринів. Антиоксидантна дія вітаміну зберігається за високих концентрацій активних форм кисню (Evstigneeva, 1998; Droshnev et al., 2005). Вітамін Е стабілізує клітинні мембрани та внутріклітинні утворення, що $є$ необхідною передумовою захисту ядерного хроматину та ДНК від руйнівної дії вільних радикалів (Duh and Vovk, 2009).

Найбільшою антиоксидантною активністю володіють а- та g-токофероли, причому антирадикальна активність є вищою для а-токоферолу, а антиоксидантна - g-токоферолу. а-токоферол володіє 60\% антирадикальної дії всіх жиророзчинних ендогенних антиоксидантів (Bjelenichev et al., 2002). Крім антирадикальної дії, а-токоферол має також здатність стабілізувати мембрани і утворювати комплекси 3 жирними кислотами, які сприяють до підвищення стійкості мембран до вільнорадикального окиснення (Kurtjak and Janovych, 2006). Крім стабілізуючої дії мембран, вітаміну Е притаманна також геномозахисна активність, виходячи $з$ наведених вище даних про значну кількість цієї сполуки у ядрі клітини та у складі ядерного хроматину (Bjrneboe et al., 1990). Згідно даних літератури було доведено, що як за умов in vitro, так $\mathrm{i}$ in vivo цей антиоксидантний вітамін спричиняє значний вплив нормалізації та здійснювати корекцію на структурно-функціональну організацію ядерного хроматину, ушкодженого внаслідок дії вільних радикалів та продуктів перекисного окиснення ліпідів (Gromina, 2001). Зокрема, у дослідах in vitro було доведено, що екзогенний коротколанцюговий $\mathrm{a}-$ токоферол, взаємодіючи з елементами ядерного матриксу клітин печінки інтактних та отруєних тетрахлоретаном щурів, сприяє значному підвищеню у ньому тотальної ДНК-полімеразної активності (Gromina, 2001). Правдоподібно, цей ефект лежить в основі доступності сайтів-мішеней на молекулах ДНК та білків ядерних структур для нормалізуючої взаємодії з $a$-токоферолом.

Biтамін $C$ будучи могутнім антиоксидантом, оберігає організм від бактерій і вірусів, володіє протизапальною і протиалергійною дією, зміцнює імунну систему і підсилює вплив інших антиоксидантів, таких як селен і вітамін Е (Bjelenichev et al., 2002; Staryk et al., 2012). Також вітамін С впливає на синтез ряду гормонів, у тому числі антистресових, регулює процеси кровотворення і нормалізує проникність капілярів, бере участь у синтезі білка колагену, який необхідний для росту клітин, тканин, кісток і хрящів організму, покращує здатність організму засвоювати кальцій, виводить токсини, регулює обмін речовин (Gultekin et al., 2001; Gutyj, 2015).

Антиоксидантні властивості вітаміну C реалізуються в організмі двома шляхами (Bjelenichev et al., 2002). Перший шлях зумовлений тим, що аскорбінова кислота, активно впливає на перебіг більшості окисно-відновних реакцій, є потужним балансстабілізувальним модулятором метаболічних процесів у тканинах організму. Другий шлях антиоксидантної дії віта- 
міну C реалізується в опосередкованій участі вітаміну в руйнуванні пероксиду водню і пов'язаний із досить сильним стимулювальним впливом на каталазну активність (Gunchak et al., 2010).

Позитивна дія аскорбінової кислоти на активність каталази зумовлена конфігурацією активного центру цього ензиму. Каталаза належить до категорії ферумвмісних ензимів $\left(\mathrm{Fe}^{2+}-\mathrm{Fe}^{3+}\right)$, а антиоксидантна дія аскорбінової кислоти реалізується завдяки активній участі цього вітаміну в процесах регенерації відновленої форми феруму на шляху знешкодження в організмі високоактивної молекулярної структури $\left(\mathrm{Fe}^{3+}\right.$ $\mathrm{O}^{-}$). Антиоксидантні ефекти вітаміну можуть виявлятися і опосередкованим чином через його позитивний вплив на метаболізм феруму в організмі тварин, зокрема - стимуляцію процесів засвоєння цього металу шляхом створення оптимальних умов для його всмоктування у травному каналі. Слід зазначити, що йони маргану підсилюють біологічні ефекти вітаміну С, a йони кобальту сприяють іiі депонуванню в тканинах Gromova and Rebrov, 2007).

За наявності відповідної кількості вітаміну С значно збільшується стійкість вітамінів А, E, B , B євої та пантенонової кислот. Після застосування антиоксидантів вітаміну Е і селену разом з вітамоном С посилюється їх дія.

Вітамін $P$ відносять до речовин, які не синтезуються в організмі, тому він повинен надходити з кормом. У кишечнику, розчинившись у воді, флавоноїди швидко всмоктуються у кров. Антиоксидантна дія вітаміну $\mathrm{P}$ тобто рутину, реалізується, аналогічно вітаміну C, шляхом його прямого регуляторного впливу на перебіг багатьох окисно-відновних реакцій в організмі. 3 іншого боку, вітамін Р є досить ефективним стабілізатором вітаміну С в організмі людини: рутин захищає L-аскорбінову кислоту від окиснення, зберігаючи таким чином іiі тканинні резерви (Bjelenichev et al., 2002). Це, у свою чергу, сприяє пролонгуванню біохімічних ефектів, у тому числі антиоксидантних властивостей вітаміну С в організмі людини.

Рутин та кверцетин володіють ефективною антиоксидантною дією, так як і вітамін E (Bjelenichev et al., 2002). Однак на відміну від останнього вони можуть зв'язуватися з іонами металів і надавати ще вираженішу захисну дію. Наприклад, комплекс «рутин плюс ферум» у п'ять разів активніше самого рутина. Саме таким чином, ці сполуки є захисниками клітин організму. Тому що перешкоджають руйнівному впливу шкідливих окиснених речовин, зберігають молодість організму, зміцнюють імунітет, попереджають виникнення різних хвороб (Gutyj, 2013).

Селен - біологічно активний мікроелемент, що входить до складу ряду гормонів і ензимів. Виробляє глутатіонпероксидазу, яка сприяе підтримці антиоксидантної активності за цих умов нейтралізує вільні радикали. Вкрай важливий для утворення білків в організмі, підтримує нормальну роботу печінки і захист щитоподібної залози, зміцнює імунну систему, є компонентом сперми, необхідний для підтримки репродуктивної функції (Gutyj, 2013).
Мікроелемент селен концентрується в організмі, головним чином, у нирках, печінці, кістковому мозку, серці, підшлунковій залозі, легенях, шкірі, нігтях і волоссі (Nazaruk et al., 2016).

Селен виконує такі функції в організмі: підсилює імунітет організму тобто стимулює утворення антитіл, білих кров'яних клітин, клітин-кілерів, макрофагів та інтерферону, бере участь у виробленні еритроцитів. Крім того є сильним антиоксидантом (перешкоджає розвитку пухлинних процесів і старіння організму, нейтралізує і виводить чужорідні речовини, активує вітамін E) (Bilash et al., 2011). До того ж знижує ризик розвитку серцево-судинних захворювань; запобігає м'язову дистрофію серця, нейтралізує токсини, стимулює синтез гемоглобіну, бере участь у виробленні еритроцитів; запобігає і призупиняє розвиток злоякісних пухлин. Крім того входить до складу більшості гормонів, ензимів і деяких білків; стимулює процеси обміну речовин в організмі; захищає організм від токсичних проявів гідріргіуму, кадмію, плюмбуму, талію та аргентуму; стимулює репродуктивну функцію (входить до складу сперматозоїдів); зменшує гострий розвиток запальних процесів; стабілізує роботу нервової системи; нормалізує роботу ендокринної системи (Mel'nychuk et al., 2003).

Селен є одним із найпотужніших антиоксидантів, основна функція якого - інгібування процесу перекисного окиснення ліпідів (Velychko, 2014). Він захищає клітини від руйнівної дії вільних радикалів, сприяє утворенню антитіл, білих кров'яних тілець, «КлітинУбивць», які знищують бактерії і рак. Забезпечує утворення макрофагів, інтерферону (найважливішого противірусного білка), запобігає гепатиту, важких інфекційних захворювань (Khariv et al., 2016; Martyshuk et al., 2016).

Антиоксидантні властивості селену виявляються на шляху активації одного з ключових ензимів системи функціонування глутатіону - глутатіонпероксидази. За недостатності цього металу в організмі порушується утворення активної форми глутатіонпероксидази, що, у свою чергу, супроводжується суттєвими перебоями в роботі всієї глутатіонової системи (Bilash et al., 2010; Gutyj, 2013).

Цинк є одним із життєво важливих мікроелементів для правильного функціонування імунної системи. Він бере участь у метаболізмі жирних кислот. Як сильний антиоксидант, захищає організм від руйнівної дії вільних радикалів (Kropyvka, 2010). Цинк, володіючи сам по собі антиоксидантними властивостями, входить до складу антиоксидантного ензиму супероксиддисмутази (Sen'kiv, 2008). Він також необхідний для підтримання нормального рівня вітаміну E у крові та сприяє абсорбції вітаміну А. Іншою важливою функцією цього мінералу є підтримка нормальної функції залоз внутрішньої секреції та імунітету (Danchuk et al., 2001).

Убіхінон відіграє важливу роль у процесах синтезу енергії в організмі, бере участь в окисно-відновних реакціях в організмі, нормалізує обмін речовин в організмі, регулює рівень холестеролу, необхідний для розвитку ембріону, відновлює антиоксидантну активність вітаміну E (Bjelenichev et al., 2002). 
<smiles>COC1C(=O)C(C)=C(CC=C(C)C)C(=O)C1OC</smiles>

Також слід відзначити, що убіхінон сприяє утворенню еритроцитів, стимулює процес кровотворення, відіграє важливу роль у процесі скорочення серцевого м'яза і роботі скелетної мускулатури (Bjelenichev et al., 2002).

Убіхінон є єдиним антиоксидантом, який регенерується організмом. Як антиоксидант захищає клітинні мембрани, ліпопротеїдні частинки і ДНК від руйнівної дії агресивних форм кисню. Убіхінон напряму пов'язують $з$ ефективністю роботою імунної системи і уповільненням процесів старіння організму в людей (Bjelenichev et al., 2002).

Церулоплазмін - багатофункціональний ензим, який у своєму складі містить купрум. Він являє собою глікопротеїд альфа-глобулінової фракції плазми крові. Згідно сучасної класифікації церулоплазмін є купрумвмісною оксидазою, яка бере участь у транспорті купруму. Він зв'язує більше 95\% загальної кількості купруму, що міститься в сироватці крові. Молекула церулоплазміну складається 31046 амінокислотних залишків, містить близько 8\% вуглеводів і 6-7 атомів міді (Bjelenichev et al., 2002; Gutyj, 2013).

Основна фізіологічна роль церулоплазміну визначається його участю в окисно-відновнювальних реакціях. Діючи як ферроксидаза, церулоплазмін виконує найважливішу роль у регуляції іонного стану феруму - окисненні $\mathrm{Fe}^{2+}$ в $\mathrm{Fe}^{3+}$. Це робить можливим включення феруму в трансферин без утворення токсичних продуктів феруму. Підтримання нормального транспорту і метаболізму феруму - життєво важлива функція церулоплазміну. Останнім часом була доведена його антиоксидантна роль (Bjelenichev et al., 2002). Церулоплазмін може діяти як прооксиданти або як антиоксидант залежно від різних факторів. За наявності супероксиду, він виступає каталізатором окиснення ліпопротеїдів низької щільності. На підставі результатів епідеміологічних досліджень, церулоплазмін розглядається як незалежний фактор ризику серцево-судинних захворювань (Gutyj, 2013).

Церулоплазмін є одним з основних антиоксидантів плазми крові. Особливістю даного білка $є$ висока стабільність до токсичної дії активних форм кисню, що дозволяє йому зберігати біологічну активність в умовах інтенсивної генерації активних форм кисню (Bjelenichev et al., 2002).

Даний білок проявляє як специфічну, так і неспецифічну антиоксидантну активність. Специфічна активність, пов'язана зі зниженням рівня активних метаболітів кисню, може бути реалізована за декількома шляхами. У плазмі крові церулоплазмін окиснює $\mathrm{Fe}^{2+}$ до $\mathrm{Fe}^{3+}$, після чого окиснені йони феруму зв'язуються 3 трансферрином і транспортуються в гепатоцити і ретикулоцити (Bjelenichev et al., 2002).
Окиснення заліза церулоплазміном, на відміну від неензимного окиснення $\mathrm{Fe}^{2+}$ за наявності оксигену, не супроводжується утворенням супероксидного аніонрадикала, який $\epsilon$ пусковим продуктом вільнорадикальних реакцій та процесів перекисного окиснення ліпідів. Саме тому, в окисних реакціях за участю йонів феруму церулоплазмін виявляється антиоксидантом (Bjelenichev et al., 2002). Церулоплазмін має здатність знешкоджувати супероксидні аніон-радикали. Неспецифічна антиоксидантна активність церулоплазміну обумовлена утворенням комплексних сполук із купрумом.

Отже, однією з важливих захисних систем організму є система антиоксидантного захисту. Вона підтримує оптимальний рівень окисно-відновних процесів та забезпечує максимальну нейтралізацію побічних продуктів перекисного окиснення ліпідів.

\section{Бібліографічні посилання}

Akymyshyn, M.M., Kuz'mina, N.V., Sachko, R.G. (2014). Aktyvnist' enzymiv antyoksydantnogo zahystu v reproduktyvnyh organah koriv za normy ta patologii'. Nauk. visnyk LNUVMBT im. S.Z. G'zhyc'kogo. L'viv. 16, 2(59), 3-9 (in Ukrainian).

Antonjak, G.L., Babych, N.O., Sologub, L.I. (2000). Utvorennja aktyvnyh form kysnju ta systema antyoksydantnogo zahystu $\mathrm{v}$ organizmi tvaryn. Biologija tvaryn. 2(2), 34-43 (in Ukrainian).

Baglaj, O.M., Murs'ka, S. D., Gutyj, B.V., Gufrij, D.F. (2011). Systema antyoksydantnogo zahystu ta perekysne okysnennja lipidiv organizmu tvaryn. Naukovyj visnyk L'vivs'kogo nacional'nogo universytetu veterynarnoi' medycyny ta biotehnologij im. G'zhyc'kogo. 13, 4(2), 3-11 (in Ukrainian).

Baraboj, V.A., Shestakova, E.N. (2004). Selen: biologichna rol' ta antyoksydantna aktyvnist'. Ukr. biohim. zhurn. 76(1), 23-32 (in Ukrainian).

Bilash, Ju.P., Cisaryk, O.J., Vudmaska, I.V. (2011). Biohimichnyj profil' plazmy krovi vidgodivel'nyh bugajciv za riznogo vmistu selenu i vitaminu E u racioni. Naukovyj visnyk LNUVMBT imeni S.Z. G'zhyc'kogo. 13, 4(50), 35-38 (in Ukrainian).

Bilash, Ju.P., Didovych, A.P., Vudmaska, I.V. (2010). Vplyv kil'kosti selenu i vitaminu E u racioni koriv na zhyrnokyslotnyj sklad moloka. Naukovyj visnyk LNUVMBT imeni S.Z. G'zhyc'kogo. 12, 3(45), 8-13 (in Ukrainian).

Binkevych, V.Ja., Gutyj, B.V., Mykytyn, L.Je., Novotni, F., Lesho, B. (2012). Biohimichni funkcii' helatnyh z'jednan' mikroelementiv u organizmi tvaryn. Naukovyj visnyk L'vivs'kogo nacional'nogo universytetu veterynarnoi' medycyny ta biotehnologij im. G'zhyc'kogo. 14, 2(3), 3-7 (in Ukrainian).

Bjelenichev, I.F., Kovalenko, S.I., Dunajev, V.V. (2002). Antyoksydanty: suchasne ujavlennja, perspektyvy stvorennja. Liky. 1, 25-29 (in Ukrainian).

Bjelenichev, I.F., Levyc'kyj, E.L., Guns'kyj, Ju.I. (2002). Antyoksydantna systema zahystu organizmu: ogljad. Suchasni problemy toksykologii'. 3, 5-17 (in Ukrainian). 
Bjelenichev, I.F., Levyc'kyj, Je.L., Kovalenko, S.I. (2002). Antyoksydantna systema zahystu organizmu (ogljad). Sovremennue problemu toksykologyy. 3, 2931 (in Ukrainian).

Bjrneboe, A., Bjrneboe, G.E., Drevon, C.A. (1990). Absorption, transport and distribution of vitamin E. J. Nutr. 120(3), 233-242 (in Russian).

Cehmistrenko, S.I. (1999). Ontogenetychni zminy aktyvnosti superoksyddysmutazy $\mathrm{v}$ organah travlennja kurchat. Visn. Bilocerkiv. derzhagrar. un-tu. 8(2), 189-194 (in Ukrainian).

Danchenko, G.V. (2002). Novi aspekty mehanizmu biologichnoi' dii' vitaminu E, jogo aktyvnyh metabolitiv ta pohidnyh. Ukrai'ns'kyj biohimichnyj zhurnal. 74(4), 8-12.

Danchuk, V.V. (2001). Aktyvnist' systemy antyoksydantnogo zahystu ta zhyrnokyslotnyj sklad membran erytrocytiv u svynej rann'ogo viku. Peredgirne ta girs'ke zemlerobstvo i tvarynnyctvo. 43(II), 52-58 (in Ukrainian).

Danchuk, V.V., Snityns'kyj, V.V., Smoljaninov, K.B. (2001). Intensyvnist' syntezu lipidiv ta aktyvnist' antyoksydantnyh fermentiv $u$ legenjah porosjat pid vplyvom cynku. Zb. nauk. prac' Odes'kogo derzh. s.g. in-u «Agrarnyj visnyk prychornomor'ja». Odesa, 4(14), 33-37 (in Ukrainian).

Droshnev, A.E., Borisova, M.N., Kostromitinov, N.A. (2005). Vlijanie vitamina E na pokazateli perekisnogo okislenija lipidov i antioksidantnoj zashhity u ryb pri stresse. Mizhvidomchij tematichnij naukovij zbirnik «Veterinarna medicina». Harkiv. 1, 395-398 (in Russian).

Dubinina, E.E., Sal'nikova, L.Ja., Efimova, L.F. (1983). Aktivnost' i izofermentnyj spektr superoksiddismutazy jeritrocytov. Lab. delo. 10, 30-33 (in Russian).

Duh, O.I., Vovk, S.O. (2009). Vmist produktiv perekysnogo okyslennja lipidiv i vitaminu E v krovi kurej vzalezhnosti vid rivnja vitaminu A v racioni. Biologichni i tehnologichni aspekty vyrobnyctva ta pererobky produkcii' tvarynnyctva $\mathrm{V}$ konteksti jevrointegracii': materialy mizhnarodnoi' naukovo konferencii'. Kamjanec'-Podil's'kyj, 44-45 (in Ukrainian).

Duh, O.I., Vovk, S.O. (2010). Zminy aktyvnosti katalazy, superoksyddysmutazy ta rivnja ceruloplazminu $\mathrm{v}$ pechinci kurej i i'hnih embrioniv zalezhno vid karotynoi'div u racioni. Ukr.biohim. zhurn. 82(4), 249250 (in Ukrainian).

Dvinskaja, L.M., Shubin, A.A. (1986). Ispol'zovanie antioksidantov v zhivotnovodstve. L.: Agropromizdat (in Russian).

Evstigneeva, R.P., Volkov, I.M., Chudinova, V.V. (1998). Vitamin E kak universal'nyj antioksidant i stabilizator biologicheskih membran. Biolog.membr. 65(2), 119135 (in Russian).

Gromina, G.A. (2001). Rol' vitaminu E v organizmi tvaryn. Vet. vrach. 3, 40-41 (in Ukrainian).

Gromova, O.A., Rebrov, V.G. (2007). Vitaminy i karcenogenez: mify i real'nost'. Trudnyj pacient. 5(3), 5-13 (in Russian)

Guberuk, V.O., Gutyj, B.V., Gufrij, D.F. (2015). Vplyv Ursovit-ADES ta selenitu natriju na aktyvnist' enzy- miv glutationovoi' systemy antyoksydantnogo zahystu organizmu bychkiv pry gostromu nitratno-nitrytnomu toksykozi. Visnyk Sums'kogo nacional'nogo agrarnogo universytetu. Serija : Veterynarna medycyna. 1, 151-154 (in Ukrainian).

Guberuk, V.O., Gutyj, B.V., Gufrij, D.F. (2015). Vplyv ursovit-ades ta selenitu natriju na riven' neenzymnoi' systemy antyoksydantnogo zahystu organizmu bychkiv za gostrogo nitratno-nitrytnogo toksykozu. Naukovyj visnyk L'vivs'kogo nacional'nogo universytetu veterynarnoi' medycyny ta biotehnologij im. G'zhyc'kogo. 17, 1(1), 3-10 (in Ukrainian).

Guberuk, V.O., Gutyj, B.V., Murs'ka, S.D., Gufrij, D.F. (2012). Riven' nefermentnoi' systemy antyoksydantnogo zahystu organizmu bychkiv pry gostromu nitratno-nitrytnomu toksykozi. Biologija tvaryn. 14(1-2), 300-305 (in Ukrainian).

Gultekin, F., Delibas, N., Yasar, S. (2001). In vivo changes in antioxidant systems and protective role of melatonin and a combination of vitamin $\mathrm{C}$ and vitamin $\mathrm{E}$ on oxidative damage in erythrocytes induced by chlorpyrifos-ethyl in rats. Arch. Toxicol. 75(2), 88-96 (in Russian).

Gunchak, V.M., Gufrij, D.F., Gutyj, B.V., Vasiv, R.O., Hariv, I.I., Homyk, R.I., Guberu, V.O. (2010). Vplyv gostrogo nitratno-nitrytnogo toksykozu na aktyvnist' systemy antyoksydantnogo zahystu ta intensyvnist' perekysnogo okysnennja lipidiv u krovi bugajciv. Naukovyj visnyk L'vivs'kogo nacional'nogo universytetu veterynarnoi' medycyny ta biotehnologij im. G'zhyc'kogo. 12, 3(1), 35-43 (in Ukrainian).

Gunchak, V.M., Gufrij. D.F., Gutyj, B.V., Vasiv, R.O., Hariv, I.I., Homyk, R.I., Murs'ka, S.D., Guberuk, V.O. (2010). Vplyv nitratu natriju u toksychnyh dozah na systemu antyoksydantnogo zahystu ta perekysne okysnennja lipidiv u krovi bugajciv. Biologija tvaryn. 12(1), 151-158 (in Ukrainian).

Gutyj, B.V. (2013). Vplyv hlorydu kadmiju u toksychnyh dozah na glutationovu systemu antyoksydantnogo zahystu organizmu bychkiv. Veterynarna biotehnologija. 22, 112-116 (in Ukrainian).

Gutyj, B.V. (2012). Vplyv hlorydu kadmiju na intensyvnist' procesiv perekysnogo okysnennja lipidivtastan systemy antyoksydantnogozahystu organizmu shhuriv. Visnyk Sums'kogo nacional'nogo agrarnogo universytetu. Serija: Veterynarna medycyna. 7, 31-34 (in Ukrainian).

Gutyj, B.V. (2013). Riven' pokaznykiv nefermentnoi' systemy antyoksydantnogo zahystu organizmu bychkiv za umov kadmijevogo navantazhennja. Naukovyj visnyk L'vivs'kogo nacional'nogo universytetu veterynarnoi' medycyny ta biotehnologij im. G'zhyc'kogo. 15, 1(4), 40-45 (in Ukrainian).

Gutyj, B.V. (2013). Vmist vitaminiv A i E u krovi bychkiv za umov kadmijevoi' intoksykacii'. Visnyk Sums'kogo nacional'nogo agrarnogo universytetu. Serija : Veterynarna medycyna. 2, 31-33 (in Ukrainian).

Gutyj, B.V. (2013). Vplyv E-selenu na aktyvnist' glutationovoi' systemy antyoksydantnogo zahystu organizmu bugajciv pry kadmijevomu navantazhenni. Visnyk Sums'kogo nacional'nogo agrarnogo 
universytetu. Serija: Veterynarna medycyna. 9, 70-73 (in Ukrainian).

Gutyj, B.V. (2013). Vplyv E-selenu na vmist vitaminiv A i E u krovi bychkiv za umov kadmijevoi' intoksykacii'. Naukovyj visnyk L'vivs'kogo nacional'nogo universytetu veterynarnoi' medycyny ta biotehnologij im. G'zhyc'kogo. 15, 3(3), 311-314 (in Ukrainian).

Gutyj, B.V. (2013). Vplyv meveselu na vmist vitaminiv A i E u krovi bychkiv za umov kadmijevoi' intoksykacii'. Naukovyj visnyk L'vivs'kogo nacional'nogo universytetu veterynarnoi' medycyny ta biotehnologij im. G'zhyc'kogo. 15, 3(1), 78-82 (in Ukrainian).

Gutyj, B.V. (2013). Vplyv meveselu ta E-selenu na riven' pokaznykiv ne fermentnoi' systemy antyoksydantnogo zahystu organizmu bugajciv pry kadmijevomu navantazhenni. Veterynarna medycyna. 97, 419-421 (in Ukrainian).

Gutyj, B.V. (2013). Vplyv preparatu «Mevesel» na aktyvnist' enzymnoi' ta neenzymnoi' lanok antyoksydantnoi' systemy organizmu bugajciv za umov hronichnogo kadmijevogo toksykozu. Biologija tvaryn. 15(4), 39-46 (in Ukrainian).

Gutyj, B.V. (2015). Aktyvnist' systemy antyoksydantnogo zahystu organizmu bychkiv za gostrogo kadmijevogo toksykozu. Naukovyj visnyk L'vivs'kogo nacional'nogo universytetu veterynarnoi' medycyny ta biotehnologij im. G'zhyc'kogo. 17, 1(1), 31-36 (in Ukrainian).

Kava, S.J., Dmytriv, O.Ja., Ivashkiv, R.M. (2012). Aktyvnist' okysnyh procesiv i vyzhyvannja spermii'v bugai'v za dii' vidnovlenoi' formy glutationu. Naukovyj visnyk LNUVMBT imeni S.Z. G'zhyc'kogo. 14, 3(53), 100-103 (in Ukrainian).

Khariv, M., Gutyj, B., Butsyak, V., Khariv, I. (2016). Hematological indices of rat organisms under conditions of oxidative stress and liposomal preparation action. Biological Bulletin of Bogdan Chmelnitskiy Melitopol State Pedagogical University. 6(1), 276-289.

Kropyvka, S.J. (2010). Aktyvnist' fermentiv u krovi telyc' za zgodovuvannja solej selenu, cynku i kadmiju. Naukovyj visnyk LNUVMBT imeni S.Z. G'zhyc'kogo. 12, 3(45), 89-92 (in Ukrainian).

Kulinskij, V.I., Kolesnichenko, L.S. (1990), Biologicheskaja rol' glutationa. Uspehi sovremennoj biologii. 110(1), 20-33 (in Russian).

Kulinskij, V.I., Kolesnichenko, L.S. (1993). Struktura, svojstva, biologicheskaja rol' i reguljacija glutationperoksidazy. Uspehi sovremennoj biologii. 113(1), 107-122 (in Russian).

Kurtjak, B.M., Janovych, V.G. (2006). Vmist vitaminiv A i E ta produktiv perekysnogo okysnennja lipidiv $u$ plazmi krovi koriv pry parenteral'nomu vvedeni tryvitu i insolvitu v kinci stijlovogo periodu. Nauk.- tehn. bjul. In-tu biol. tvaryn. 212-214 (in Ukrainian).

Leshovs'ka, N.M., Mamchuk, N.A., Matlah, I.J. (2007). Vplyv vitaminiv A, D3, E, selenu ta interferonu na systemu antyoksydantnogo zahystu ta procesy peroksydnoi' oksydacii' lipidiv u glybokotil'nyh koriv ta i'h teljat. Biologija tvaryn. 9(1-2), 186-189 (in Ukrainian).
Leshovs'ka, N.M., Vishhur, O.I., Sologub, L.I. (2005). Vplyv vitaminiv A, D3, E, selenu ta interferonu na procesy perekysnogo okysnennja lipidiv ta antyoksydantnyj status teljat. NT Bjuleten' In-tu biologii' tvaryn, DNDKI veterynarnyh preparativ ta kormovyh dobavok. 6(1), 73-77 (in Ukrainian).

Martyshuk, T.V., Gutyj, B.V., Vishchur, O.I. (2016). Level of lipid peroxidation products in the blood of rats under the influence of oxidative stress and under the action of liposomal preparation of «Butaselmevit», Biological Bulletin of Bogdan Chmelnitskiy Melitopol State Pedagogical University. 6(2), 22-27.

Mel'nychuk, D.O., Mel'nykova, N.M., Kalinin, I.V. (2003). Vplyv selenu na vmist kadmiju u tkanynah tvaryn : mizhvidomchyj tematychnyj naukovyj zbirnyk «Aktual'ni problemy veterynarnoi' medycyny v umovah suchasnogo vedennja tvarynnyctva». Veterynarna medycyna. Feodosija. 82, 393-395 (in Ukrainian).

Mohazzab, K.M., Agarwal, R., Wolin, M.S. (1999). Influence of glutathioneperoxidase on coronary artery responses to alterations in of $\mathrm{PO} 2$ of and of $\mathrm{H} 2 \mathrm{O} 2$. J. Physiol. 276(2), 11235-11241.

Nazaruk N.V., Gutyj, B.V., Gufrij, D.F. (2015). Vplyv metifenu ta vitamiksu se na aktyvnist' aminotransferaz syrovatky krovi bychkiv za nitratno-kadmijevogo navantazhennja. Naukovyj visnyk L'vivs'kogo nacional'nogo universytetu veterynarnoi' medycyny ta biotehnologij im. G'zhyc'kogo. 17, 1(1), 121-126 (in Ukrainian).

Nazaruk, N.V., Gutyj, B.V., Murs'ka, S.D., Gufrij, D.F. (2016). Vplyv metifenu ta vitamiksu Se na riven' vitaminiv A i E u krovi bychkiv za nitratno-kadmijevogo navantazhennja. Visnyk Sums'kogo nacional'nogo agrarnogo universytetu. Serija Veterynarna medycyna. 6, 27-30 (in Ukrainian).

Ponkalo, L.I. (2012). Intensyvnist' procesiv peroksydnogo okysnennja lipidiv ta aktyvnist' glutationovoi' systemy antyoksydantnogo zahystu u til'nyh koriv ta i'h teljat za dii' novyh imunotropnyh zasobiv u vygljadi liposomal'noi' emul'sii'. Naukovyj zhurnal. Biologija tvaryn. L'viv, 14(1-2), 551-557 (in Ukrainian).

Popyk, I.M. (2012). Vplyv riznyh doz vitaminu A na stan pro- $\mathrm{j}$ antyoksydantnoi' system u krovi koropa. Naukovyj zhurnal. Biologija tvaryn. L'viv. 14(1-2), 184188 (in Ukrainian).

Sen'kiv, O. M. (2008). Vplyv cynku na aktyvnist' fermentiv antyoksydantnoi' systemy $\mathrm{v}$ krovi porosjat pry vidluchenni i'h vid svynomatok. Naukovo-tehnichnyj bjul. 9(1, 2), 58-61 (in Ukrainian).

Staryk, L.I., Gutyj, B.V., Vasiv, R.O., Gufrij, S.D. Murs'ka, D.F. (2012). Vplyv sukupnogo vvedennja pirydoksynu gidrohlorydu $\mathrm{z}$ askorbinovoju kyslotoju na biohimichni ta morfologichni pokaznyky krovi bychkiv pry gostromu nitratno-nitrytnomu toksykozi. Naukovyj visnyk L'vivs'kogo nacional'nogo universytetu veterynarnoi' medycyny ta biotehnologij im. G'zhyc'kogo. 14, 2(1), 306-312 (in Ukrainian).

Vasyliv, O., Gnatush, S. (2011). Vplyv spoluk ferumu ta manganu na vmist glutationu $\mathrm{u}$ klitynah sirkovidnovljuval'nyh bakterij Desulfuromonas acetoxidans. Biologichni studii'. 5(1), 5-10 (in Ukrainian). 
Velychko, V.O. (2014). Rol' mikroelementiv u formuvanni systemy antyoksydantnogo zahystu porosjat pry stresovyh stanah. Nauk. visnyk LNUVMBT im. S.Z. G'zhyc'kogo. L'viv. 16, 2(59), 57-63 (in Ukrainian).

Vishhur, O.I. (2006). Vplyv preparatu «Antoksan» na procesy perekysnogo okysnennja lipidiv ta glutationovu systemu antyoksydantnogo zahystu porosjat pislja vidluchennja vid svynomatok. Veterynarna biotehnologija. Bjuleten' IVM UAAN. K. : Agrarna nauka, 9, 32-42 (in Ukrainian).

Vlasova, S.N., Shabunina, E.I., Pereslegina, I.A. (1990). Aktivnost' glutationzavisimyh fermentov jeritrocitov pri hronicheskih zabolevanijah pecheni u detej. Lab. delo. 8, 19-22 (in Russian).

Vorobec', N.M. (2004). Glutationperoksydaza aktyvnist' roslyn za dii' ioniv svyncju. Nauk.- tehn. bjul. In-tu biol. tv. UAAN. 5(1-2), 111-114 (in Ukrainian).

Zavijs'kyj, Ju. (2005). Antyoksydanty i antyoksydantna systema organizmu ljudyny. Visnyk Prykarpats'kogo nacional'nogo universytetu imeni Vasylja Stefanyka. Serija biologija. 5, 107-118 (in Ukrainian).

Стаття надійшла до редакиії 5.09.2016 